\title{
Antimicrobial Activity of Methanol Extract from Ficus carica Leaves Against Oral Bacteria
}

\author{
Mi-Ran Jeong ${ }^{1}$, Hye-Young Kim ${ }^{2}$ and Jeong-Dan Cha ${ }^{*}$ \\ ${ }^{1}$ Research Center of Bioactive Materials, Chonbuk National University, Jeonju, Korea \\ ${ }^{2}$ Department of Dental Hygiene, College of Natural Sciences, Dongeui University, Busan, Korea \\ Oral Cancer Research Institute, College of Dentistry, Yonsei University, Seoul, Korea
}

Ficus carica L. (fig) belongs to the mulberry tree (Moraceae) which is one of the oldest fruits in the world. It has been used as a digestion promoter and a cure for ulcerative inflammation and eruption in Korea. The present study investigated the antimicrobial activity of methanol $(\mathrm{MeOH})$ extract of figs against oral bacteria. The $\mathrm{MeOH}$ extract (MICs, 0.156 to $5 \mathrm{mg} / \mathrm{ml}$; MBCs, 0.313 to $5 \mathrm{mg} / \mathrm{ml}$ ) showed a strong antibacterial activity against oral bacteria. The combination effects of $\mathrm{MeOH}$ extract with ampicillin or gentamicin were synergistic against oral bacteria. We suggest that figs could be employed as a natural antibacterial agent in oral care products.

Key Words: Ficus carica (fig), Antibacterial activity, MIC/MBC, Synergistic

\section{INTRODUCTION}

Ficus carica Linn. (Syn: Ficus sycomorous; family: Moraceae) is commonly referred as "“Fig". The cultivated Fig, native to the arid region of Asia Minor, forms a shrub or low-spreading deciduous tree. The large, wavy-margined leaves are usually 5 lobed but may have only 4 or 3 lobes (1). Its fruit, root and leaves are used in the native system of medicine in various disorders such as gastrointestinal (colic, indigestion, loss of appetite and diarrhea), respiratory (sore throats, coughs and bronchial problems), inflammatory, cardiovascular disorders, ulcerative diseases, and cancers $(1 \sim 5)$. F. carica has been reported to have numerous bioactive compounds such as arabinose, $\beta$-amyrins, $\beta$ carotines, glycosides, $\beta$-setosterols and xanthotoxol (5 7).

Received: April 2, 2009/ Revised: April 27, 2009

Accepted: May 4, 2009

* Corresponding author: Dr. Jeong-Dan Cha. Oral Cancer Research Institute, College of Dentistry, Yonsei University, 250 Seongsanno, Seodaemun-gu, Seoul, 120-752, Korea.

Phone: +82-2-2228-3142, Fax: +82-2-392-2959,

e-mail: joungdan@yuhs.ac
The researchers reported the hypoglycemic action of a fig leaf decoction in type-I diabetic patients and used a chloroform extract, obtained also from a decoction of F. carica leaves, to decrease the cholesterol levels of rats with diabetes (8). F. carica has been reported to include antioxidant, antiviral, antibacterial, hypoglycemic, hypocholesterolaemic, cancer suppressive, hypotriglyceridaemic, and anthelmintic effects $(2 \sim 4,9 \sim 11)$. It has also been investigated for its proteolytic enzymes, amino acids, minerals, sugars, triterpenes, organic acids, and allergens $(1,6)$.

This study was aimed at providing the antimicrobial activities of $F$. carica (figs) $\mathrm{MeOH}$ extract against oral bacteria.

\section{MATERIAL AND METHODS}

\section{Plant material and preparation of methanol extract}

F. carica leaves were collected in September 2005 from the Samho farm of Yeongam-gun in Korea. The identity was confirmed by Dr. Bong-Seop Kil, College of Natural Science, Wonkwang University. The voucher specimens 
(DJ-05-F1) were deposited at the Herbarium of the College of Natural Science, Wonkwang University. The dried and powered leaves $(1.2 \mathrm{~kg})$ of $F$. carica were extracted by repeated refluxing with methanol $(\mathrm{MeOH})(2 \times 6 \mathrm{~L})$ for 4 $\mathrm{h}$ at $80^{\circ} \mathrm{C}$. The combined $\mathrm{MeOH}$ extract $(12 \mathrm{~L})$ was clarified by filtration and evaporated to obtain dark green syrup $(210 \mathrm{~g})$

\section{Minimum inhibitory concentration/minimum bacteri- cidal concentration assay}

The antimicrobial activity of the $\mathrm{MeOH}$ extract of $F$. carica leaves against oral bacteria: Streptococcus mutans (ATCC 25175), Streptococcus sanguinis (ATCC 10556), Streptococcus sobrinus (ATCC 27607), Streptococcus ratti (KCTC 3294), Streptococcus criceti (KCTC 3292), Streptococcus anginosus (ATCC 31412) and Streptococcus gordonii (ATCC 10558), Aggregatibacter actinomycetemcomitans (ATCC 43717), Fusobacterium nucleatum (ATCC 51190), Prevotella intermedia (ATCC 49046), and Porphyromonas gingivalis (ATCC 33277) was determined through the broth dilution method carried out in triplicate. The reference strains used in this study were: Escherichia coli ATCC 25922, Staphylococcus aureus ATCC 29213, Staphylococcus epidermidis ATCC 12228, and Streptococcus pyogenes ATCC 21059.

The minimum inhibitory concentration (MIC) was determined as the lowest concentration of test samples that resulted in a complete inhibition of visible growth in the broth. Following anaerobic incubation of MIC plates, the minimum bactericidal concentration (MBC) was determined on the basis of the lowest concentration of the $\mathrm{MeOH}$ extract that kill $99.9 \%$ of the test bacteria by plating out onto each appropriate agar plate.

\section{Checker board dilution test}

The synergistic effects of the $\mathrm{MeOH}$ extract, which exhibited the highest antimicrobial activity and antibiotics, were assessed by the checkerboard test as previously described (12). The antimicrobial combinations assayed included the $\mathrm{MeOH}$ extract plus ampicillin or gentamicin. The (FICI) is the sum of the FICs of each of the drugs, which in turn is defined as the MIC of each drug when it is used in combination divided by the MIC of the drug when it is used alone. The interaction was defined as synergistic if the FICI was less than or equal to 0.5 , additive if the FICI was greater than 0.5 and less than or equal 1.0, indifferent if the FICI was greater than 1.0 and less than or equal to 2.0, and antagonistic if the FICI was greater than 2.0 (12).

\section{RESULTS}

The results of the antibacterial activity showed that the $\mathrm{MeOH}$ extract of $F$. carica leaves exhibited strong activities against $S$. gordonii, S. anginosus, $P$. intermedia, A. actinomycetemcomitans, and $P$. gingivalis (MIC, 0.156 to 0.625 $\mathrm{mg} / \mathrm{ml}$; MBC, 0.313 to $0.625 \mathrm{mg} / \mathrm{ml}$ ), and moderate antibacterial activity against the other bacteria (MIC, $1.25 \mathrm{mg}$ ) $\mathrm{ml}$; MBC, 1.25 to $2.5 \mathrm{mg} / \mathrm{ml}$ ), while E. coli, S. aureus, $S$. sanguinis, and S. criceti appeared to be less sensitive (MIC, 2.5 to $10 \mathrm{mg} / \mathrm{ml}$; MBC, 2.5 to $10 \mathrm{mg} / \mathrm{ml}$ ). The MIC and MBC for ampicillin were found to be either $0.5 / 0.5$ or $256 /$ $256 \mu \mathrm{g} / \mathrm{ml}$; for gentamicin, either $2 / 2$ or $256 / 512 \mu \mathrm{g} / \mathrm{ml}$ (Table 1, 2).

The combination effects of $\mathrm{MeOH}$ extract with ampicillin or gentamicin against oral bacteria and a few reference strains were presented in Tables 1,2 . In combination with $\mathrm{MeOH}$ extract, the MIC for ampicillin was reduced $\geq 4-8$ fold and $\mathrm{MeOH}$ extract indicated $\geq 2-8$-fold in most of tested bacteria, producing a synergistic effect as defined by FICI $\leq 0.375 \sim 0.5$. The additive effect of $\mathrm{MeOH}$ extract with ampicillin combination led to a reduction of a single or double dilution in E. coli, S. ratti, and F. nucleatum, and as defined by $\mathrm{FICI} \leq 0.75$ (Table 1 ).

The combination of the $\mathrm{MeOH}$ extract with gentamicin resulted in the decrease in MIC for all tested bacteria ( $\geq 2$-8-fold), with the MIC of $0.5 \sim 32 \mu \mathrm{g} / \mathrm{ml}$ for gentamicin becoming 2 256 $\mu \mathrm{g} / \mathrm{ml}$ and MIC of $0.039 \sim 2.5 \mathrm{mg} / \mathrm{ml}$ for the $\mathrm{MeOH}$ extract becoming $0.156 \sim 10 \mathrm{mg} / \mathrm{ml}$. The FICI classified the combination of the $\mathrm{MeOH}$ extract with gentamicin as a synergistic effect $(\mathrm{FICI} \leq 0.375 \sim 0.5)$ for all tested bacteria except an additive effect, such as $S$. pyogenes, S. sanguinis, S. criceti, P. intermedia, and F. nucleatum (Table 2). 
Table 1. Checkerboard assay of the $\mathrm{MeOH}$ extract of F. carica leaves and ampicillin for some oral bacteria with a few reference strains

\begin{tabular}{|c|c|c|c|c|c|c|}
\hline \multirow{2}{*}{ Strains } & \multirow{2}{*}{ Agent } & \multicolumn{2}{|c|}{$\mathrm{MIC} / \mathrm{MBC}^{\mathrm{a}}$} & \multirow{2}{*}{$\mathrm{FIC}^{\mathrm{c}}$} & \multirow{2}{*}{$\mathrm{FICI}^{\mathrm{c}}$} & \multirow{2}{*}{ Outcome } \\
\hline & & Alone & Combination $^{\mathrm{b}}$ & & & \\
\hline \multirow{2}{*}{$\begin{array}{l}\text { E. coli } \\
\text { ATCC } 25922\end{array}$} & $\mathrm{MeOH}$ & $10 / 10$ & $5 / 5$ & 0.5 & \multirow{2}{*}{0.75} & \multirow{2}{*}{ Additive } \\
\hline & Ampicillin & $256 / 256$ & $64 / 64$ & 0.25 & & \\
\hline \multirow{2}{*}{$\begin{array}{l}\text { S. aureus } \\
\text { ATCC } 29213\end{array}$} & $\mathrm{MeOH}$ & $2.5 / 2.5$ & $0.625 / 0.625$ & 0.25 & \multirow{2}{*}{0.5} & \multirow{2}{*}{ Synergistic } \\
\hline & Ampicillin & $16 / 16$ & $4 / 8$ & 0.25 & & \\
\hline \multirow{2}{*}{$\begin{array}{l}\text { S. epidermidis } \\
\text { ATCC } 12228\end{array}$} & $\mathrm{MeOH}$ & $1.25 / 1.25$ & $0.313 / 0.625$ & 0.25 & \multirow{2}{*}{0.5} & \multirow{2}{*}{ Synergistic } \\
\hline & Ampicillin & $32 / 64$ & $8 / 16$ & 0.25 & & \\
\hline \multirow{2}{*}{$\begin{array}{l}\text { S. pyogenes } \\
\text { ATCC } 21059\end{array}$} & $\mathrm{MeOH}$ & $1.25 / 2.5$ & $0.313 / 0.625$ & 0.25 & \multirow{2}{*}{0.5} & \multirow{2}{*}{ Synergistic } \\
\hline & Ampicillin & $4 / 8$ & $1 / 1$ & 0.25 & & \\
\hline \multirow{2}{*}{$\begin{array}{l}\text { S. mutans } \\
\text { ATCC } 25175\end{array}$} & $\mathrm{MeOH}$ & $1.25 / 1.25$ & $0.313 / 0.313$ & 0.25 & \multirow{2}{*}{0.5} & \multirow{2}{*}{ Synergistic } \\
\hline & Ampicillin & $0.5 / 0.5$ & $0.125 / 0.125$ & 0.25 & & \\
\hline \multirow{2}{*}{$\begin{array}{l}\text { S. sanguinis } \\
\text { ATCC } 10556\end{array}$} & $\mathrm{MeOH}$ & $2.5 / 2.5$ & $0.313 / 0.625$ & 0.125 & \multirow{2}{*}{0.375} & \multirow{2}{*}{ Synergistic } \\
\hline & Ampicillin & $1 / 4$ & $0.25 / 0.5$ & 0.25 & & \\
\hline \multirow{2}{*}{$\begin{array}{l}\text { S. sobrinus } \\
\text { ATCC } 27607\end{array}$} & $\mathrm{MeOH}$ & $1.25 / 2.5$ & $0.313 / 0.313$ & 0.25 & \multirow{2}{*}{0.375} & \multirow{2}{*}{ Synergistic } \\
\hline & Ampicillin & $0.125 / 0.5$ & $0.0156 / 0.0312$ & 0.125 & & \\
\hline \multirow{2}{*}{$\begin{array}{l}\text { S. ratti } \\
\text { KCTC } 3294\end{array}$} & $\mathrm{MeOH}$ & $1.25 / 2.5$ & $0.625 / 0.625$ & 0.5 & \multirow{2}{*}{0.75} & \multirow{2}{*}{ Additive } \\
\hline & Ampicillin & $1 / 2$ & $0.25 / 0.5$ & 0.25 & & \\
\hline S. criceti & $\mathrm{MeOH}$ & $2.5 / 5.0$ & $0.625 / 0.625$ & 0.25 & 05 & Syneroistic \\
\hline КСТС 3292 & Ampicillin & $1 / 1$ & $0.25 / 0.5$ & 0.25 & 0.5 & Synnergisuc \\
\hline S. anginosus & $\mathrm{MeOH}$ & $0.625 / 0.625$ & $0.156 / 0.156$ & 0.25 & 05 & Syneroistic \\
\hline ATCC 31412 & Ampicillin & $0.5 / 1$ & $0.125 / 0.25$ & 0.25 & 0.0 & syitergistic \\
\hline S. gordonii & $\mathrm{MeOH}$ & $0.156 / 0.313$ & $0.039 / 0.078$ & 0.25 & 05 & Syneroistic \\
\hline ATCC 10558 & Ampicillin & $1 / 1$ & $0.25 / 0.25$ & 0.25 & 0.0 & 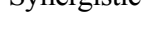 \\
\hline A. actinomycetemcomitans & $\mathrm{MeOH}$ & $0.625 / 0.625$ & $0.156 / 0.156$ & 0.25 & 05 & Syneroistic \\
\hline ATCC 43717 & Ampicillin & $32 / 32$ & $8 / 16$ & 0.25 & 0.0 & 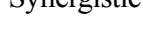 \\
\hline F. nucleatum & $\mathrm{MeOH}$ & $1.25 / 1.25$ & $0.0 .625 / 0.625$ & 0.5 & 0.75 & Additive \\
\hline ATCC 51190 & Ampicillin & $2 / 4$ & $0.5 / 1$ & 0.25 & & \\
\hline P. intermedia & $\mathrm{MeOH}$ & $0.313 / 0.313$ & $0.078 / 0.156$ & 0.25 & 05 & Syneroistic \\
\hline ATCC 49049 & Ampicillin & $8 / 8$ & $2 / 2$ & 0.25 & 0.0 & \\
\hline P. gingivalis & $\mathrm{MeOH}$ & $0.625 / 0.625$ & $0.156 / 0.156$ & 0.25 & 05 & Syneroistic \\
\hline ATCC 33277 & Ampicillin & $0.5 / 1$ & $0.125 / 0.125$ & 0.25 & 0.0 & syitigisic \\
\hline
\end{tabular}

${ }^{\mathrm{a}}$ The $\mathrm{MeOH}$ extract: $\mathrm{mg} / \mathrm{ml}$, ampicillin: $\mu \mathrm{g} / \mathrm{ml}$

${ }^{\mathrm{b}}$ The checkerboard test was performed as previously described (12). The MICs and MBCs of the MeOH extract with ampicillin against oral bacteria are indicated.

${ }^{\mathrm{c}}$ The interaction was defined as synergistic if the FICI was less than or equal to 0.5 , additive if the FICI was greater than 0.5 and less than or equal 1.0, indifferent if the FICI was greater than 1.0 and less than or equal to 2.0, and antagonistic if the FICI was greater than 2.0 (12) 
Table 2. Checkerboard assay of the $\mathrm{MeOH}$ extract of F. carica leaves and gentamicin for some oral bacteria with a few reference strains

\begin{tabular}{|c|c|c|c|c|c|c|}
\hline \multirow{2}{*}{ Strains } & \multirow{2}{*}{ Agent } & \multicolumn{2}{|c|}{$\mathrm{MIC} / \mathrm{MBC}^{\mathrm{a}}$} & \multirow{2}{*}{$\mathrm{FIC}^{\mathrm{c}}$} & \multirow{2}{*}{$\mathrm{FICI}^{\mathrm{c}}$} & \multirow{2}{*}{ Outcome } \\
\hline & & Alone & Combination $^{\mathrm{b}}$ & & & \\
\hline \multirow{2}{*}{$\begin{array}{l}\text { Escherichia coli } \\
\text { ATCC } 25922\end{array}$} & $\mathrm{MeOH}$ & $10 / 10$ & $2.5 / 2.5$ & 0.25 & \multirow{2}{*}{0.5} & \multirow{2}{*}{ Synergistic } \\
\hline & Gentamicin & $16 / 16$ & $4 / 8$ & 0.25 & & \\
\hline \multirow{2}{*}{$\begin{array}{l}\text { Staphylococcus aureus } \\
\text { ATCC } 29213\end{array}$} & $\mathrm{MeOH}$ & $2.5 / 2.5$ & $0.625 / 1.25$ & 0.25 & \multirow{2}{*}{0.5} & \multirow{2}{*}{ Synergistic } \\
\hline & Gentamicin & $2 / 2$ & $0.5 / 0.5$ & 0.25 & & \\
\hline \multirow{2}{*}{$\begin{array}{l}\text { Staphylococcus epidermidis } \\
\text { ATCC } 12228\end{array}$} & $\mathrm{MeOH}$ & $1.25 / 1.25$ & $0.313 / 0.625$ & 0.25 & \multirow{2}{*}{0.5} & \multirow{2}{*}{ Synergistic } \\
\hline & Gentamicin & $2 / 2$ & $0.5 / 1$ & 0.25 & & \\
\hline \multirow{2}{*}{$\begin{array}{l}\text { Streptococcus pyogenes } \\
\text { ATCC } 21059\end{array}$} & $\mathrm{MeOH}$ & $1.25 / 2.5$ & $0.625 / 0.625$ & 0.5 & \multirow{2}{*}{0.75} & \multirow{2}{*}{ Additive } \\
\hline & Gentamicin & $8 / 16$ & $2 / 2$ & 0.25 & & \\
\hline \multirow{2}{*}{$\begin{array}{l}\text { S. mutans } \\
\text { ATCC } 25175\end{array}$} & $\mathrm{MeOH}$ & $1.25 / 1.25$ & $0.313 / 0.313$ & 0.25 & \multirow{2}{*}{0.5} & \multirow{2}{*}{ Synergistic } \\
\hline & Gentamicin & $8 / 16$ & $2 / 4$ & 0.25 & & \\
\hline \multirow{2}{*}{$\begin{array}{l}\text { S. sanguinis } \\
\text { ATCC } 10556\end{array}$} & $\mathrm{MeOH}$ & $2.5 / 2.5$ & $0.625 / 1.25$ & 0.25 & \multirow{2}{*}{0.75} & \multirow{2}{*}{ Additive } \\
\hline & Gentamicin & $32 / 64$ & $16 / 16$ & 0.5 & & \\
\hline \multirow{2}{*}{$\begin{array}{l}\text { S. sobrinus } \\
\text { ATCC } 27607\end{array}$} & $\mathrm{MeOH}$ & $1.25 / 2.5$ & $0.313 / 0.625$ & 0.25 & \multirow{2}{*}{0.5} & \multirow{2}{*}{ Synergistic } \\
\hline & Gentamicin & $8 / 8$ & $2 / 2$ & 0.25 & & \\
\hline \multirow{2}{*}{$\begin{array}{l}\text { S. ratti } \\
\text { KCTC } 3294\end{array}$} & $\mathrm{MeOH}$ & $1.25 / 2.5$ & $0.313 / 0.625$ & 0.25 & \multirow{2}{*}{0.5} & \multirow{2}{*}{ Synergistic } \\
\hline & Gentamicin & $16 / 32$ & $4 / 8$ & 0.25 & & \\
\hline S. criceti & $\mathrm{MeOH}$ & $2.5 / 5.0$ & $0.625 / 1.25$ & 0.25 & 075 & Additive \\
\hline КСТС 3292 & Gentamicin & $8 / 8$ & $4 / 4$ & 0.5 & 0.13 & Audinve \\
\hline S. anginosus & $\mathrm{MeOH}$ & $0.625 / 0.625$ & $0.156 / 0.156$ & 0.25 & 05 & Syneroistic \\
\hline ATCC 31412 & Gentamicin & $32 / 64$ & $8 / 16$ & 0.25 & 0.0 & 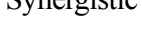 \\
\hline S. gordonii & $\mathrm{MeOH}$ & $0.156 / 0.313$ & $0.039 / 0.078$ & 0.25 & 05 & Syneroistic \\
\hline ATCC 10558 & Gentamicin & $32 / 64$ & $8 / 16$ & 0.25 & 0.0 & जуना \\
\hline A. actinomycetemcomitans & $\mathrm{MeOH}$ & $0.625 / 0.625$ & $0.156 / 0.156$ & 0.25 & 05 & Sunoroictic \\
\hline ATCC 43717 & Gentamicin & $8 / 8$ & $2 / 4$ & 0.25 & 0.0 & 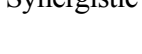 \\
\hline F. nucleatum & $\mathrm{MeOH}$ & $1.25 / 1.25$ & $0.313 / 0.313$ & 0.25 & 0.75 & Additive \\
\hline ATCC 51190 & Gentamicin & $4 / 4$ & $2 / 2$ & 0.5 & & \\
\hline P. intermedia & $\mathrm{MeOH}$ & $0.313 / 0.313$ & $0.078 / 0.078$ & 0.25 & 075 & Additive \\
\hline ATCC 25611 & Gentamicin & $16 / 32$ & $8 / 8$ & 0.5 & 0.10 & 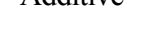 \\
\hline P. gingivalis & $\mathrm{MeOH}$ & $0.625 / 0.625$ & $0.156 / 0.156$ & 0.25 & 0375 & Syneroistic \\
\hline ATCC 33277 & Gentamicin & $256 / 512$ & $32 / 64$ & 0.125 & 0.010 & syأigisti \\
\hline
\end{tabular}

${ }^{a}$ The $\mathrm{MeOH}$ extract: $\mathrm{mg} / \mathrm{ml}$, gentamicin: $\mu \mathrm{g} / \mathrm{ml}$

${ }^{\mathrm{b}}$ The checkerboard test was performed as previously described (12). The MICs and MBCs of the MeOH extract with gentamicin against oral bacteria are indicated.

${ }^{\mathrm{c}}$ The interaction was defined as synergistic if the FICI was less than or equal to 0.5 , additive if the FICI was greater than 0.5 and less than or equal 1.0, indifferent if the FICI was greater than 1.0 and less than or equal to 2.0, and antagonistic if the FICI was greater than 2.0 (12) 


\section{DISCUSSION}

The phytochemical analysis reveals that the aqueous extract of ripe dried fruit of $F$. carica contains alkaloids, flavonoids, coumarins, saponins, and terpenes $(6,13)$. Some phenolic compounds, with reported pharmacological properties have already been isolated from fig leaves, namely furanocoumarins like psoralen and bergapten, flavonoids like rutin, quercetin, and luteolin, phenolic acids like ferrulic acid, and also phytosterols like taraxasterol $(6,7)$. Phenolic compounds constitute an important class of phytochemicals which possess diverse biological activities like astringent, antioxidant, anticancer, anti-inflammation, and antibacterial activity, etc $(2,6,14)$. In this study, the antibacterial activity of the $\mathrm{MeOH}$ extract of F. carica leaves showed strong activities against $S$. gordonii, $S$. anginosus, $P$. intermedia, A. actinomycetemcomitans, and $P$. gingivalis (MIC, 0.156 to $0.625 \mathrm{mg} / \mathrm{ml}$; MBC, 0.313 to $0.625 \mathrm{mg} / \mathrm{ml})$. Some phenolic compounds isolated from plants exhibit anticaries activity either due to growth inhibition against mutans streptococci or due to the inhibition of glucosyltransferases (15). As several reports have demonstrated that some flavonoid compounds evidence antibacterial activity against oral bacteria (16), it is generally considered that the flavonoids in F. carica may be related, in part, to the antibacterial effects observed in the present study. The synergistic effects of the $\mathrm{MeOH}$ extract with ampicillin or gentamicin combination against oral bacteria were presented as $\geq 4$-8-fold reduction of MIC, producing a synergistic effect as defined by $\mathrm{FICI} \leq 0.375 \sim$ 0.5 . Especially, $\mathrm{MeOH}$ extract with ampicillin or gentamicin combination showed the strongest synergistic effect (FICI $\leq 0.375$ ) against $S$. sanguinis, $S$. sobrinus, and $P$. gingivalis.

The water extract and ethyl acetate and hexane fractions from methanol extracts from the leaves of F. carica have been demonstrated as anti-HSV-1 effect and insecticidal activity against Tetranychus urticae $(9,17)$. The administration of the basic and chloroform extracts of F. carica affect the oxidative stress in diabetes, with particular significance regarding the vitamin $\mathrm{E} / \mathrm{C} 18: 2$ ratio when the chloroform fraction is administered, and the vitamin $\mathrm{A} / \mathrm{C} 18: 2$ ratio with the basic fraction (8). The 6-O-acyl- $\beta$-d-glucosyl- $\beta$-sitosterols along with its palmitoyl, linoleyl, stearyl and oleyl derivatives isolated from the fruit of F. carica exhibited strong cytotoxic effect (2). The F. carica leaves are composed of many flavonoids then it may perhaps indicate strong antibacterial activity against oral bacteria.

These findings suggest that a strong bactericidal effect was exerted in drug combinations. The F. carica leaves fulfill the conditions required for a novel agent against cariogenic bacteria and periodontal pathogens and could be employed as a natural antibacterial agent in oral care products.

\section{Acknowledgements}

We thank Prof. B. S. Kil, College of Natural Science, Wonkwang University for the confirmation of plant authenticity.

\section{REFERENCES}

1) McGovern TW. The fig-Ficus carica L. Cutis 2002; 69:339-40.

2) Rubnov S, Kashman Y, Rabinowitz R, Schlesinger M, Mechoulam R. Suppressors of cancer cell proliferation from fig (Ficus carica) resin: isolation and structure elucidation. J Nat Prod 2001;64:993-6.

3) Perez C, Canal JR, Campillo JE, Romero A, Torres MD. Hypotriglyceridaemic activity of Ficus carica leaves in experimental hypertriglyceridaemic rats. Phytother Res 1999;13:188-91.

4) Canal JR, Torres MD, Romero A, Perez C. A Chloroform extract obtained from a decoction of Ficus carica leaves improves the cholesterolaemic status of rats with streptozotocin-induced diabetes. Acta Physiol Hung 2000;87:71-6

5) Gilani AH, Mehmood MH, Janbaz KH, Khan AU, Saeed SA. Ethnopharmacological studies on antispasmodic and antiplatelet activities of Ficus carica. J Ethnopharmacol 2008;119:1-5.

6) Vaya J, Mahmood S. Flavonoid content in leaf extracts of the fig (Ficus carica L.), carob (Ceratonia siliqua L.) and pistachio (Pistacia lentiscus L.). Biofactors 2006; 
28:169-75.

7) Ross JA, Kasum CM. Dietary flavonoids: bioavailability, metabolic effects, and safety. Annu Rev Nutr 2002;22: 19-34.

8) Pèrez C, Canal JR, Torres MD. Experimental diabetes treated with Ficus carica extract: effect on oxidative stress parameters. Acta Diabetol 2003;40:3-8.

9) Wang G, Wang H, Song Y, Jia C,Wang Z, Xu H. Studies on anti-HSV effect of Ficus carica leaves. Zhong Yao Cai 2004;27:754-6.

10) Solomon A, Golubowicz S, Yablowicz Z, Grossman $S$, Bergman M, Gottlieb HE, Altman A, Kerem Z, Flaishman MA. Antioxidant activities and anthocyanin content of fresh fruits of common fig (Ficus carica L.). J Agric Food Chem 2006;54:7717-23.

11) Jeong MR, Cha JD, Lee YE. Antibacterial activity of Korean Fig (Ficus carica L.) against food poisoning bacteria. Korean J Food Cookery Sci 2005;21:84-93.

12) Jung EK. Antimicrobial activity of extract and fractions from Drynaria fortunei against oral bacteria. J Bacteriol Virol 2007;37:61-8.
13) Teixeira DM, Patão RF, Coelho AV, da Costa CT. Comparison between sample disruption methods and solid-liquid extraction (SLE) to extract phenolic compounds from Ficus carica leaves. J Chromatogr A 2006; 1103:22-8

14) Ryu SR, Cho H, Jung JS, Jung ST. The study on the separation and antitumor activity as new substances in fig. J Applied Chem 1998;2:961-4.

15) Hada S, Kakiuchi N, Hattori M, Namba T. Identification of antibacterial principles against Streptococcus mutans and inhibitory principles against glucosyltransferase from the seed of Areca catechu L. Phytother Res 1989; 3:140-4.

16) Cha JD, Jeong MR, Jeong SI, Lee KY. Antibacterial activity of sophoraflavanone $\mathrm{G}$ isolated from the roots of Sophora flavescens. J Microbiol Biotechnol 2007; 17:858-64.

17) Chon SU, Kim DI, Kang KS. Insecticidal potential of methanol extract and its fractions from Fig (Ficus carica L.) leaves. Korean J Pest Sci 2008;12:243-8. 